Western University

Scholarship@Western

Biology Publications

Biology Department

$3-1-2013$

\title{
Identification of cold-responsive genes in a New Zealand alpine stick insect using RNA-Seq.
}

Luke T Dunning

Alice B Dennis

Duckchul Park

Brent J Sinclair

Richard D Newcomb

See next page for additional authors

Follow this and additional works at: https://ir.lib.uwo.ca/biologypub

Part of the Biology Commons

Citation of this paper:

Dunning, Luke T; Dennis, Alice B; Park, Duckchul; Sinclair, Brent J; Newcomb, Richard D; and Buckley, Thomas R, "Identification of cold-responsive genes in a New Zealand alpine stick insect using RNA-Seq." (2013). Biology Publications. 80.

https://ir.lib.uwo.ca/biologypub/80 
Authors

Luke T Dunning, Alice B Dennis, Duckchul Park, Brent J Sinclair, Richard D Newcomb, and Thomas R Buckley 


\section{Identification of cold-responsive genes in a New Zealand alpine stick insect using RNA-Seq}

\section{Luke T. Dunning ${ }^{1,2,3}$, Alice B. Dennis ${ }^{1,3}$, Duckchul C. Park ${ }^{1}$, Brent J.} Sinclair ${ }^{4}$, Richard D. Newcomb ${ }^{2,3,5}$, Thomas R. Buckley ${ }^{1,2,3}$

${ }^{1}$ Landcare Research, Private Bag 92170, Auckland, New Zealand

${ }^{2}$ School of Biological Sciences, University of Auckland, Auckland, New Zealand

${ }^{3}$ Allan Wilson Centre for Molecular Ecology and Evolution, New Zealand

${ }^{4}$ Department of Biology, The University of Western Ontario, London, ON, Canada N6G 1 L3

${ }^{5}$ The New Zealand Institute for Plant \& Food Research Limited, Auckland, New Zealand

Corresponding Author:

Luke T. Dunning

Landcare Research, Private Bag 92170, Auckland, New Zealand tel: +6495744155

Dunningl@landcareresearch.co.nz

\section{Abstract}

The endemic New Zealand alpine stick insect Micrarchus nov. sp. 2 regularly experiences sub-zero temperatures in the wild. 454-based RNA-Seq was used to generate a de novo transcriptome and differentiate between treatments to investigate the genetic basis of cold tolerance. Non cold-treated individuals were compared to those exposed to $0{ }^{\circ} \mathrm{C}$ for $1 \mathrm{~h}$ followed by a $1 \mathrm{~h}$ recovery period at $20{ }^{\circ} \mathrm{C}$. We aligned 607,410 Roche 454 reads, generating a transcriptome of 5,235 contigs. Differential expression analysis ranked candidate cold responsive genes for $\mathrm{qPCR}$ validation by $P$-value. The top nine up-regulated candidates, together with eight a priori targets identified from previous studies, had their relative expression quantified using qPCR. Three candidate cold responsive genes from the RNA-Seq data were verified as significantly up-regulated, annotated as: prolyl 4-hydroxylase subunit alpha-1 (P4HA1), staphylococcal nuclease domain-containing protein 1 (snd1) and cuticular protein analogous to peritrophins 3-D2 (Cpap3-d2). All three are novel candidate genes, illustrating the varied response to low temperature across insects.

Keywords: stick insect, 


\section{Introduction}

Temperature is a critical variable affecting the performance and distribution of insects (Chown and Nicolson, 2004). The New Zealand alpine zone was formed approximately 5 Mya ago during the Kaikoura Orogeny (Batt and Braun, 1999; Batt et al., 2000; Chamberlain and Poage 2000). This recent origin has led to substantial adaptive radiation with all major New Zealand insect lineages represented in alpine habitats (Buckley and Simon, 2007); in particular, the incidence of alpine stick insects (order Phasmatodea) is globally unusual (Salmon, 1991). Out of the 23 endemic New Zealand species from 10 genera (Buckley and Bradler, 2010), only Micrarchus nov. sp. 2 (Voucher specimen NZAC03009458 from New Zealand Arthropod Collection, Landcare Research, Auckland, New Zealand) is exclusively found at high elevations ( 600 to $1,409 \mathrm{~m}$ above sea level). This species inhabits the mountain ranges of the north-west South Island, which regularly experience sub-zero temperatures throughout the year (Salmon, 1991). All life stages of this species overwinter (A.B. Dennis and L.T. Dunning, unpublished observations), with those alive at the end of the summer capable of surviving through until spring. At low temperatures all insects need to mitigate problems associated with reduced cell membrane fluidity (Overgaard et al., 2005), changes in ion concentration (Koštál et al., 2007), induction of apoptotic pathways and other non-freezing cold injuries (Bale, 2002). In addition, lower sub-freezing temperatures lead to a risk of internal ice formation, against which cold-hardy alpine insects adopt freeze avoidant or freeze tolerant strategies (Wharton, 2011). In New Zealand, the majority of alpine insects survive by being moderately freeze tolerant with no incidence of freeze avoidance currently recorded (Wharton, 2011). Nothing is known about cold tolerance in any stick insects. Very little is known concerning the genes underpinning cold tolerance in cold-hardy insects, as most studies focus on chill-susceptible Drosophila species (Hoffmann, 2010). However, Drosophila studies have identified a number of candidate genes associated with the molecular response to cold. The most prominent include heat shock proteins (Qin et al., 2005) and the Frost gene (Goto, 2001). A plethora of other genes and proteins have also been identified as up-regulated in response to low temperature in a variety of insects, with functions related to stress, metabolism, cuticles, membranes, gene regulation, cytoskeletal and immune function (Denlinger and Lee, 2010; Teets et al., 2012). Many of those identified do not overlap between species (Qin et al., 2005; Colinet et al., 2007; Robich et al., 2007; Clark and Worland, 2008; Li and Denlinger, 2008; Denlinger and Lee, 2010); we expect that this diversity reflects interspecific variation in response to cold, and is not solely a product of differing methodologies. Additionally, cold tolerance is plastic over both short-term (rapid cold hardening; Lee et al., 1987) and long-term (seasonal acclimation) temporal scales. Gene expression is not essential for this plasticity (Sinclair et al., 2007) but underpins long term responses to, preparation for, and recovery 
from cold-shock. To fully comprehend the molecular mechanisms underpinning the variation in insect responses to the cold there is a need to extend genome-based studies beyond the Diptera, in particular to include insects that experience sub-zero temperatures in the wild. High-throughput sequencing (HTS) and RNA-Seq have allowed the investigation of species that are not established genetic models, yet display adaptations that make them pertinent to an array of ecological and physiological questions (Wang et al., 2009). However, RNA-Seq is still to be applied explicitly to cold tolerant insects and their response to low temperature (Storey and Storey, 2012). Methods previously adopted to identify genes differentially expressed as a consequence of low temperature include cDNA library screening (Bilgen et al., 2001), suppressive subtractive hybridisation (SSH; Rinehart et al., 2007; Robich et al., 2007) microarrays (Qin et al., 2005; Laayouni et al., 2007; Sørensen et al., 2007; Purać et al., 2008; Zhang et al., 2011; Teets et al., 2012) and quantitative real-time PCR (qPCR; Clark and Worland, 2008). Although microarrays have the potential to provide whole-transcriptome snapshots, the ability to identify novel transcriptional profiles associated with cold tolerance is limited by the original starting material used to construct a cDNA array (Wang et al., 2009). Even with genome-based arrays (such as those used for Drosophila), there is a limited ability to distinguish between splice variants, patterns of allelic expression and to quantify low abundant transcripts (Wang et al., 2009). By applying HTS to insects across a range of cold-tolerance phenotypes it will not only be possible to uncover novel genes but also allow the development of a more complete picture of the complexity and common features that underlie insect cold tolerance.

In this study, we use HTS and de novo transcriptome alignment to identify novel candidate genes associated with recovery from cold-shock in Micrarchus nov. sp. 2, a cold-hardy stick insect currently lacking genomic resources.

\section{Materials and Methods}

\subsection{Field collections}

Alpine Micrarchus nov. sp. 2 specimens were collected from Sewell Peak, the Paparoa Range, New Zealand $\left(42^{\circ} 24.312 \mathrm{~S}, 171^{\circ} 20.585 \mathrm{E}\right.$, elevation $\left.822 \mathrm{~m}\right)$. Samples for HTS at the University of Otago, HTS at Landcare Research and quantitative RT-PCR (qPCR) were collected on the 20/03/2009, 11/02/2011 and 27/01/2012, respectively. At Sewell Peak, temperatures in late summer can still drop to a few degrees above freezing (A.B. Dennis and T.R. Buckley, unpubl. observations). Collections were transported live to Landcare Research, Auckland. They were kept en masse in a vivarium for a minimum period of 3 weeks for acclimatisation in 12:12 light:dark cycle under ambient room temperature and humidity prior to experimentation. A constant diet of freshly collected pōhutukawa (Metrosideros excelsa) was provided. All subsequent procedures were performed exclusively on adult females. 


\subsection{Cold-shock treatments}

108 The control groups were snap frozen in liquid nitrogen directly from approximately $20^{\circ} \mathrm{C}$. Cold-shock experiments were performed immediately afterwards. The stick insects were held at $0{ }^{\circ} \mathrm{C}$ for $1 \mathrm{~h}$ in 50 $\mathrm{mL}$ Falcon tubes that had been pre-immersed in ice baths. A $1 \mathrm{~h}$ recovery at approximately $20^{\circ} \mathrm{C}$ followed this treatment. Previous studies associating cold exposure to gene expression have used a similar temperature and recovery period (Goto, 2001; Sinclair et al., 2007; Teets et al., 2012). We expect that Micrarchus nov. sp. 2 would potentially encounter $0{ }^{\circ} \mathrm{C}$ in the field at any time of year (A.B. Dennis \& T.R. Buckley, unpublished observations). All insects survived the treatment and were moving in a coordinated fashion at the end of the recovery period. Insects were then directly snap frozen and stored at $-80^{\circ} \mathrm{C}$.

\subsection{RNA extraction and CDNA synthesis}

All experiments used the head, antennae and prothorax of the animals. These were removed with sterilised scalpel blades and ground in liquid nitrogen using a mortar and pestle. mRNA was extracted using Dynabeads mRNA DIRECT ${ }^{\mathrm{TM}}$ Kit (Invitrogen, Carlsbad, CA, USA; cat. no. 610.06) following the manufacturer's protocol, with one amendment; samples were passed through QIAshredder columns (Qiagen, Hilden, Germany, cat. no. 79656) for sample homogenisation and DNA shearing. RNA quantity was determined by spectrophotometry prior to cDNA library construction (Roche, Mannheim, Germany, "cDNA Rapid Library Preparation Method Manual-GS FLX Titanium Series", October 2009 (Rev. Jan 2010)). Individual libraries were tagged with MID-labelled primers during preparation. cDNA Libraries were sent to the University of Otago High-Throughput DNA Sequencing Unit for purification and sequencing on a Roche 454 GS FLX sequencer. To increase the number of reads for de novo transcriptome assembly, two additional samples were sequenced at Landcare Research (Auckland). Total RNA was extracted using the TRIzol (Invitrogen, cat. no. 15596-018) RNA isolation method, followed by mRNA purification using the Oligotex mRNA Spin-

132 Column Protocol (Qiagen, Hilden, Germany, cat. no. 70022). Quality and concentration of RNA extractions was assessed using a NanoDrop ND-1000 spectrophotometer (NanoDrop Technologies, Wilmington, DE, USA) and an Agilent 2100 Bioanalyzer (Agilent Technologies, Palo Alto, CA, USA). cDNA libraries were constructed using the cDNA Rapid Library Preparation Manual Method (Roche, Mannheim, Germany, GS Junior Titanium Series, May 2010 (Rev. June 2010)). Individual libraries were tagged with MID-labelled primers during preparation. Library quality was assessed using the Agilent 2100 Bioanalyzer and TBS 380 Fluorometer (Turner Biosystems, Sunny-vale, CA, USA). Sequencing was performed on a 454 GS Junior (Roche, Mannheim, Germany). 
For qPCR samples, total RNA was extracted using TRIzol (Invitrogen, cat. no. 610.06) according to the manufacturer's protocol. A further RNA clean-up was performed using the RNeasy Mini Kit (Qiagen, cat. no. 74104). Quality and concentration of RNA extractions were assessed using a NanoDrop ND-1000 spectrophotometer. Contaminating DNA was removed using the Ambion DNA-free ${ }^{\mathrm{TM}}$ DNase Treatment kit (Invitrogen, cat. no. AM1906). The first strand cDNA synthesis used the SuperScript III First Strand Kit (Invitrogen, cat. no. 18080-051). Successful DNase treatment and cDNA preparation were verified using post and pre cDNA synthesis samples as a template for PCR. Glyceraldehyde 3-phosphate (G3P, F1 = 5'TGCCAGGCAGTTGGTGGTGC-3', R1 = 5'-ATTCGGCCGCATCGGTCGCC-3'), which amplifies products from both genomic DNA and cDNA (442 bp), was used to check for successful removal of genomic DNA from pre cDNA synthesis templates. Enolase primers (ENO, F1 = 5'-AGCACTACCACGGAAAGGGGGT-3', R1 = 5'ACCATGGTGCCCCAGCCATT-3') amplify an approximately 1,000 bp product from cDNA only and successful amplification was an indication of cDNA quality. PCRs consisted of $2.5 \mu \mathrm{L}$ of $2 \mathrm{mM}$ dNTP (Roche, Mannheim, Germany), $1 \mu \mathrm{L}$ of $10 \mu \mathrm{M}$ bovine serum albumin (Sigma-Aldrich, St Louis, MO, USA), $2.5 \mu \mathrm{L}$ of 10X FastStart Taq DNA Polymerase PCR Buffer with MgCl2 (Roche), 1.5 U FastStart Taq DNA Polymerase (Roche) and $10 \mathrm{pmol}$ of the forward and reverse primers (Sigma-Aldrich) in a total volume of $25 \mu \mathrm{L}$. Amplifications were performed on a GeneAmp PCR system 9700 thermal cycler (Applied Biosystems, Foster City, CA, USA) using the following parameters: 5 min at $95^{\circ} \mathrm{C} ; 40$ cycles of $1 \mathrm{~min}$ at $94{ }^{\circ} \mathrm{C}, 1 \mathrm{~min}$ at $60^{\circ} \mathrm{C}$ and $1 \mathrm{~min}$ at $72{ }^{\circ} \mathrm{C}$; and $10 \mathrm{~min}$ at $72{ }^{\circ} \mathrm{C}$. Successful amplification was assessed by gel electrophoresis on $1 \%$ agarose gels containing $0.5 \mathrm{mg} \mathrm{mL}^{-1}$ ethidium bromide.

\subsection{4 transcriptome alignment}

Sequences were cleaned, trimmed and aligned using Newbler GS De novo Assembler (V. 2.5.3).

Redundancy within the alignment was removed using the Geneious (Drummond et al., 2012) de novo assembler with two different sequence similarity cut-offs (custom sensitivity with default parameters, minimum overlap $=40 \mathrm{bp}$ and sequence similarity $=100 \%$ or $90 \%$ ). Reassembled Isotigs (putative genes and their splice variants) are subsequently referred to as contigs and were manually checked to assess validity and to ensure they were not the result of repetitive DNA (e.g. microsatellites). The alignment was annotated using Blast2GO (Conesa et al., 2005) on the $4^{\text {th }}$ of September 2011 against the $\mathrm{nr}$ and SwissProt databases (minimum e-value cut-off $<1^{-10}$ ). To identify non annotated contigs selected for qPCR verification from the differential expression (DE) analysis, the contig sequences were searched against an unpublished Illumina transcriptome from the same species (L.T. Dunning et al. unpublished). Any matching Illumina contigs that were longer were subsequently searched against the SwissProt and nr databases.

\subsection{Sequence counts and differential expression}


Sequence counts for each individual contig were generated by mapping the Newbler-trimmed data back onto the alignment using PanGEA (v. 1.04) (Kofler et al., 2009). Reads retained for further analysis had to map unambiguously to one contig, have a minimum alignment length of $40 \mathrm{bp}$, incorporate $>20 \%$ of the read length and a minimum sequence similarity of $85 \%$. To be considered for subsequent DE analysis each contig had to have a combined total of at least ten counts.

DE analysis in R (V. 2.13.0) (R Development Core Team, 2012) used DESeq (V. 1.4.1) (Anders and Huber, 2010), edgeR (V. 2.2.5) (Robinson et al., 2010) and baySeq (V. 1.6.0) (Hardcastle and Kelly, 2010) packages. DESeq and edgeR are similar exact test approaches, whereas baySeq employs a Bayesian method to assign likelihoods to specified models. All methods use the negative binomial distribution that compensates for higher levels of biological than technical variation. Raw counts were normalised for library size using the calcNormFactors and estimateSizeFactors functions in edgeR and DESeq, respectively. The quantile normalised counts from edgeR were used for subsequent analysis in baySeq. In edgeR both common and the more stringent tagwise dispersion methods for estimating DE were used. Two models were specified for analysis in baySeq; equal expression between all samples and differential expression between the control and cold-shocked treatments. baySeq calculated DE with and without transcript length as an additional normalisation factor. Analysis was performed with 10,000 iterations and 100 bootstraps.

\section{6 qPCR verification}

The results of the DE analysis were ranked by $P$-value or likelihood depending on the R package used. Subsequent qPCR verification of candidate cold tolerance genes was performed. Eight a priori genes (Table 3) identified as differentially expressed or with a possible role in cold tolerance from previous studies found in the de novo transcriptome were also targeted, along with alkb5 (selected by eye from corrected sequence counts). In addition, three stably expressed genes identified by DE analysis ( $P$-value $>0.8 ;>1,000$ counts) across treatments were selected as references to normalise relative expression levels among genes. These were: glyceraldehyde-3-phosphate dehydrogenase 2 (g3p2), paramyosin long form (mysp1) and elongation factor 1-alpha 2 (ef1a2). Primers were designed with stringent criteria using the Primer3 (Rozen and Helen, 2000) plugin in Geneious (Drummond et al., 2012). All primers had a Tm of $59-61{ }^{\circ} \mathrm{C}$ (except NADH_F1 Tm $=57.62{ }^{\circ} \mathrm{C}$ ), GC content between $40-60 \%$, were 18 25 base pairs long and amplify a product between 60-150 bp in length (Supplementary material A). qPCR was performed using LightCycler 480 SYBR Green I Master mix (Roche, Mannheim, Germany, cat. no. 04707516001$), 0.25 \mu \mathrm{M}$ each primer and approximately $5 \mathrm{ng}$ of template cDNA with a total reaction volume of $10 \mu \mathrm{l}$. Reactions were carried out on a LightCycler 480 (Roche, Mannheim, Germany) with the default cycling parameters and $60^{\circ} \mathrm{C}$ annealing temperature. Two treatments (control versus coldshock) with three biological repeats, each with three technical repeats and three negative controls 
210 were, carried out per gene. All genes were analysed in two 384-well plates. A preliminary run and 211 subsequent melting curve analysis was used to exclude genes where more than one product was 212 amplified. Quantification cycle $\left(C_{q}\right)$ values for each reaction were calculated using LinRegPCR 213 (Ramakers et al., 2003). Primer efficiencies were calculated on average for each gene. Technical replicates where the efficiency was greater than $5 \%$ of the mean were excluded from subsequent analysis. The most suitable reference genes and normalisation factors were calculated using geNorm (Vandesompele et al., 2002) based on the geometric means. For the first plate ef1a2 and mysp1 were selected and for the second plate $g 3 p 2$ and mysp1 were used. An approximate Pfaffl (Pfaffl, 2001) method generated relative amounts of each target gene. The raw relative expression values were natural log transformed and a one tailed t-test used to access significant differential expression between treatments.

\section{Results}

223

\subsection{Transcriptome generation}

Four individually-tagged cDNA libraries, each constructed from the head, antennae and prothorax of a single Micrarchus nov. sp. 2, were sequenced on the Roche 454 GS FLX platform producing a total of 524,120 sequences (Table 1). This dataset was supplemented with a further 83,112 Roche 454 GS Junior sequences from two cDNA libraries constructed from the head, antennae and prothorax of additional individuals. The resulting 607,410 sequences comprised $291,936,440$ nucleotides with a median read length of $482 \mathrm{bp}$ ( mean $=481 ; S D=112$ ). Raw data were submitted to the National Centre for Biotechnology and Information (NCBI) (Sequence Read Archive (SRA) submission number SRA057228). After trimming to remove bases with low quality scores, adapters and MID barcodes there were 514,993 (84.79\%) sequences, 150,267,849 (51.47\%) nucleotides and a median sequence length of $313 \mathrm{bp}($ mean $=292 ; S D=99)$.

235 An initial Newbler alignment produced 5,827 isotigs longer than $50 \mathrm{bp}$ with a median length of $593 \mathrm{bp}$ 236 (mean = 843; SD 928). These belonged to 4,490 isogroups (putative genes). To remove redundancy the alignment was reassembled using the Geneious de novo assembler (Drummond et al., 2012) which reduced the number of contigs to 5,235 . This new alignment incorporated $78 \%$ of the original sequence data with a median contig length of $588 \mathrm{bp}$ (mean = 819; SD 884). The longest contig was 20,518 bp (BLASTx to SwissProt identified this contig as a cDNA encoding Twitchin). 1,058 contigs were longer than 1,000 bp and 3,240 contigs were greater than $500 \mathrm{bp}$. Sequence counts were generated by mapping the Newbler trimmed reads back onto the alignment. Between $65-67 \%$ of raw reads (total = 327,870 sequences) for each sample mapped back to 2,602 contigs that had a combined total at least ten counts; these were used for subsequent differential expression analysis. 
245 The complete de novo transcriptome was annotated (with an $E$-value $<1^{-10}$ ) using three approaches: (1)

246 BLASTn against the non redundant (nr) protein database identified 2,630 (50 \%) contigs, (2) BLASTx

247 against $\mathrm{nr}$ database identified 2,060 (39\%) contigs and (3) BLASTx against the SwissProt database 248 identified 1,991 (38 \%) contigs. All contigs are subsequently referred to by their top BLAST match.

249 Nineteen of the 20 most commonly hit species for the lowest $E$-value BLASTx match against the $\mathrm{nr}$ 250 database (Figure 1) were insects, apart from Daphnia pulex. In spite of polyA selection during cDNA 251 library preparation, a substantial number of rRNA sequences remained (17-22\% of reads from each sample were identified as $18 \mathrm{~S}$ and $28 \mathrm{~S}$ rRNA).

\subsection{Expression analysis}

Relative mRNA abundances were compared between cold-exposed ( $1 \mathrm{~h}$ at $0{ }^{\circ} \mathrm{C}$ followed by $1 \mathrm{~h}$ at $20^{\circ} \mathrm{C}$ ) and control (kept at $20^{\circ} \mathrm{C}$ throughout) individuals to identify differentially-expressed candidate coldresponsive genes. Using edgeR with common dispersion two down-regulated contigs were detected (adjusted $P$-value of $<0.05$ ) during recovery from cold-shock. The other tests did not reveal any further candidates with the limited biological replication $(n=2)$ resulting in high false discovery rates. A relaxation of the stringency to uncorrected $P$-value was permitted as qPCR should identify any false positives. Using edgeR with common dispersion 168 contigs were identified as differentially expressed (94 up, 74 down, $P$-value < 0.05) (Figure 2). The edgeR with tagwise dispersion analysis identified 106 differentially expressed contigs (56 up, 50 down, $P$-value $<0.05$ ). DESeq identified 10 differentially expressed contigs ( 7 up, 3 down, P-value < 0.05). The baySeq analyses identified 2 up-regulated contigs (likelihood $>0.80$ ). A full list of all significant differentially regulated genes can be found in Supplementary material C. Up-regulated contigs during recovery from cold-shock were ranked by $P$-value, with the top four from each of the five analyses shown in Table 2 ( $n=11$ due to redundancy between results). No common contig was identified by the five approaches, but staphylococcal nuclease domain-containing protein 1 (snd1) was in the top four differentially expressed contigs for at least one of the analyses in the three $\mathrm{R}$ packages implemented (edgeR, DESeq and baySeq).

\section{3 qPCR verification} Of the eleven candidates identified from RNA-Seq differential expression analysis as up-regulated (Table 2), nine were verified using qPCR with samples from new biological replicates $(n=3)$ exposed to the same treatments. Of the nine genes, three were statistically significantly up-regulated in coldexposed individuals (Figure 3). These were prolyl 4-hydroxylase subunit alpha-1 (P4HA1, $P$-value = $0.0327)$, snd1 $(P$-value $=0.0065)$ and cuticular protein analogous to peritrophins 3-D2 $(C p a p 3-d 2, P$ - 
value $=0.0469)$. None of the eight cold-responsive genes (Table 3 ) selected a priori from the literature were significantly differentially expressed (Figure 3).

\section{Discussion}

This study exploits recent developments in HTS and de novo transcriptomics to investigate the genetic basis of cold tolerance in an alpine New Zealand stick insect. This is the first study to apply RNA-Seq specifically to cold-hardy insects and their response to mild cold exposure. No prior assumption or genomic information was required to discover three novel cold-responsive genes.

We identified three robust candidate genes that are up-regulated in response to a mild cold shock in Micrarchus nov. sp. 2. These genes are snd1, P4HA1 and Cpap3-d2 and are associated with transcription, amino acid metabolism and cuticular organisation, respectively. As such, these new candidates differ in function from those identified in other insect species. The low number of genes identified in our study may be due to the response by gene expression response to cold being slow, although in Drosophila the window of acute gene expression response to cold-shock starts to decline after three hours (Sinclair et al., 2007). We note that few genes with acute responses to cold exposure have been identified in Drosophila (Qin et al., 2005), and that longer recovery leads to the up-regulation of different gene sets in that species (Zhang et al., 2011). The limited biological replication $(n=2)$ for the RNA-Seq and differential expression analysis likely led to a high false discovery rate. However, the conservative two-tier approach of RNA-Seq coupled with subsequent qPCR validation corrects for Type 1 error and allows confidence in the three cold-responsive genes we identified. However, it is likely that with further power and a wider range of treatment and recovery conditions, it will be possible to identify additional cold-responsive genes in this species.

No orthologues selected a priori from the literature showed differential expression in response to cold exposure in Micrarchus nov. sp. 2. However, because of the small number of transcriptomic studies outside of Diptera, coupled with few studies using cold-hardy species, we are unable to determine whether this difference is because hemimetabolous insects and Diptera have different responses to cold, or due to $0{ }^{\circ} \mathrm{C}$ being a relatively mild cold stress for an alpine insect. Data loggers (A.B. Dennis \& T.R. Buckley, unpublished observations) indicate that temperatures in the microhabitat are quite stable near $0{ }^{\circ} \mathrm{C}$ beneath snow pack and that (even in the summer) $0{ }^{\circ} \mathrm{C}$ is a temperature experienced during a cold night, suggesting that $0{ }^{\circ} \mathrm{C}$ is ecologically-relevant for this species. We are also unable to determine whether the observed changes indicate a repair response to damage, or a preparatory response associated with acclimation to cold. As the RNA-Seq approach becomes more widely adopted, it will be possible to compare cold responses in a phylogenetic context, helping to address some of these questions. 


\subsection{Cold-responsive genes}

The snd1 gene encodes a complex, six-domain, multifunctional protein with many biological functions (Ying and Chen, 2012; Sundstrom et al., 2009). Snd1 is cleaved by caspase-3-like enzymes in apoptosis (Sundstrom et al., 2009). Rapid cold-hardening in Drosophila reduces apoptosis and lowers caspase-3like protein levels (Yi et al., 2007), and we speculate that elevated expression of snd1 in cold-shocked Micrarchus nov. sp. 2 may be associated with this process. In other organisms the snd1 protein is also associated with the accumulation of mRNA into stress granules (Gao et al., 2010; Weissbach and Scadden, 2012) and the cleavage of double-stranded RNA (Caudy et al., 2003). Thus, it is possible that snd1 expression is part of a general stress response in Micrarchus nov. sp. 2, rather than being specifically cold-related. Further experiments monitoring the response of Micrarchus nov. sp. 2 to other abiotic stresses could identify if up-regulation of snd1 is cold-specific.

PAHA1 encodes an oxidoreductase enzyme catalysing the hydroxylation of proline to hydroxyproline during the maturation of collagen, and possibly other proteins (Mann et al., 1996; Shoulders and Raines, 2009; Gorres and Raines, 2010). The PAHA1 enzyme also modifies proline residues of incorrectly folded collagen after stress in human cells (Vonk et al., 2010). Thus, increased expression of the PAHA1 gene in Micrarchus nov. sp. 2 might be associated with stabilisation or the refolding of proteins that were denatured by the cold-shock treatment, or to stabilise structural peptides in anticipation of future cold exposures. The final robust candidate we identified was $C p a p 3-d 2$, which has been previously identified in genome sequences of Tribolium castaneum, Nasonia vitipennis and Acyrthosiphon pisum (Jasrapuria et al., 2010). Cpap3-d2 is associated with the epidermal cuticle of T. castaneum, and different Cpap transcripts appear to affect the rigidity of the cuticle in the elytra and hindwings (Jasrapuria et al., 2010; Dittmer et al., 2011). Increased expression of cuticular proteins has been recorded in cold-shocked and diapausing D. melanogaster (Qin et al., 2005, Baker and Russell, 2009), after cold exposure in Aphidius colemani (Colinet et al. 2007) and in overwintering Cucujus clavipes puniceus larvae (Carrasco et al., 2011). The changes in the expression of cuticular proteins with cold shock are currently unexplained, and we suggest that establishing how the cuticle structure is modified by cold shock, whether Cpap3-d2 is responsible for these changes, and how this contributes to overall cold tolerance maybe profitable avenues for future research.

\section{Conclusion} study is the first to apply high-throughput sequencing and de novo transcriptome alignment to 
specifically address the response of a cold-hardy insect species to low temperature. This method clearly offers promise for future studies of cold tolerance in non-model organisms. In the current study RNASeq was a more successful approach than screening for a priori genes from other species. This allowed us to identify three Micrarchus nov. sp. 2 genes that responded to cold-shock, but had not been identified as cold-responsive in other insects.

Acknowledgments:. We would like to thank Jacob Corcoran for guidance with qPCR, Rich Leschen, Lucy Shield and Clive Williams for assistance with fieldwork, the Greymouth Department of Conservation office for access to Sewell Peak, Melody Clark for helpful comments on the manuscript and Katya Ruggiero for statistical support. The project was funded by The Royal Society of New Zealand Marsden Fund (LCR0901), the Allan Wilson Centre for Molecular Ecology and Evolution and Core funding for Crown Research Institutes from the Ministry of Business, Innovation and Employment's Science and Innovation Group.

\section{References}

Anders, S. and Huber, W. 2010. Differential expression analysis for sequence count data. Genome Biol. 11, R106. Baker, D. and Russell, S. 2009. Gene expression during Drosophila melanogaster egg development before and after reproductive diapause. BMC Genomics 10, 242.

Bale, J.S. 2002.. Insects and low temperatures, from molecular biology to distributions and abundance. Philos. T. Roy. Soc. B 357, 849-862.

Batt, G.E. and Braun, J. 1999. The tectonic evolution of the Southern Alps, New Zealand, insights from fully thermally coupled dynamical modelling. Geophys. J. Int. 136, 403-420.

Batt, G.E., Braun, J., Kohn, B.P. and McDougall, I. 2000. Thermochronological analysis of the dynamics of the Southern Alps, New Zealand. Geol. Soc. Am. Bull. 112, 250-266.

Bilgen, T., English, T.E., McMullen, D.C. and Storey, K.B. 2001. EsMIp, a Muscle-LIM Protein Gene, Is Up-regulated during Cold Exposure in the Freeze-Avoiding Larvae of Epiblema scudderiana. Cryobiology 43, 11-20. Buckley, T.R. and Simon, C. 2007. Evolutionary radiation of the cicada genus Maoricicada Dugdale Hemiptera, Cicadoidea. and the origins of the New Zealand alpine biota. Biol. J. Linn. Soc. 91, 419-435.

Buckley, T.R. and Bradler, S. 2010. Tepakiphasma ngatikuri, a new genus and species of stick insect Phasmatodea. from the Far North of New Zealand. N. Z. Entomol. 33, 118-126.

Carrasco, M.A., Buechler, S.A., Arnold, R.J., Sformo, T., Barnes, B.M. and Duman, J.G. 2011. Elucidating the Biochemical Overwintering Adaptations of Larval Cucujus clavipes puniceus, a Nonmodel Organism, via High Throughput Proteomics. J. Proteome Res. 10, 4634-4646.

Caudy, A.A., Ketting, R.F., Hammond, S.M., Denli, A.M., Bathoorn, A.M.P., Tops, B.B.J., Silva, J.M., Myers, M.M., Hannon, G.J. and Plasterk, R.H.A. 2003. A micrococcal nuclease homologue in RNAi effector complexes. Nature 425, 411-414.

Chamberlain, C.P. and Poage, M.A. 2000. Reconstructing the paleotopography of mountain belts from the isotopic composition of authigenic minerals. Geology 28, 115-118.

Chown, S.L. and Nicolson, S.W. 2004. Insect Physiological Ecology, Mechanisms and Patterns. Oxford University Press, Oxford. 
Clark, M.S. and Worland, M. R. 2008. How insects survive the cold, molecular mechanisms-a review. J. Comp. Physiol. B 178, 917-933.

Colinet, H., Nguyen, T.T.A., Cloutier, C., Michaud, D. and Hance, T. 2007. Proteomic profiling of a parasitic wasp exposed to constant and fluctuating cold exposure. Insect Biochem. Mol. Biol. 37, 1177-1188.

Conesa, A., Götz, S., García-Gómez, J.M., Terol, J., Talón, M. and Robles, M. 2005. Blast2GO, a universal tool for annotation, visualization and analysis in functional genomics research. Bioinformatics 21, 3674-3676.

Denlinger, D.L. and Lee, R.E. 2010. Low Temperature Biology of Insects. Cambridge, Cambridge University Press Dittmer, N.T., Hiromasa, Y., Tomich, T.T., Lu, N. Beeman, R.W., Kramer, K.J and Kanost, M.R. 2011. Proteomic and transcriptomic analyses of rigid and membranous cuticles and epidermis from the elytra and hindwings of the red flour beetle, Tribolium castaneum. J. Proteome Res. 11, 269-278

Drummond, A.J., Ashton, B., Buxton, S., Cheung, M., Cooper, A., Duran, C., Field, M., Heled, J., Kearse, M., Markowitz, S., Moir, R., Stones-Havas, S., Sturrock, S., Thierer, T. and Wilson, A. 2012. Geneious v5.6, available from http,//www.geneious.com/.

Gao, X., Ge, L., Shao, J., Su, C., Zhao, H., Saarikettu, J., Yao, X., Yao, Z., Silvennoinen, O. and Yang, J. 2010. Tudor-SN interacts with and co-localizes with G3BP in stress granules under stress conditions. FEBS Lett. 584, 35253532.

Goto, S.G. 2001.. A novel gene that is up-regulated during recovery from cold shock in Drosophila melanogaster. Gene 270, 259-264.

Gorres, K.L., Raines, R.T. 2010. Prolyl 4-hydoxylase. Crit. Rev. Biochem. Mol. Biol. 45, 106-124

Hardcastle, T. and Kelly, K. 2010. baySeq, Empirical Bayesian methods for identifying differential expression in sequence count data. BMC Bioinformatics 11, 422.

Hoffmann, A.A., Hallas, R., Anderson, A.R. and Telonis-Scott, M. 2005. Evidence for a robust sex-specific trade-off between cold resistance and starvation resistance in Drosophila melanogaster. J. Evol. Biol. 18, 804-810.

Hoffmann, A. A. 2010. Physiological climatic limits in Drosophila, patterns and implications. J. Exp. Biol. 213, 870880.

Jasrapuria, S., Arakane, Y., Osman, G., Kramer, K.J., Beeman, R.W. and Muthukrishnan, S. 2010. Genes encoding proteins with peritrophin A-type chitin-binding domains in Tribolium castaneum are grouped into three distinct families based on phylogeny, expression and function. Insect Biochem. Molec. Biol. 40, $214-227$.

Kallioniemi, E. and Hanski, I. 2011. Interactive effects of Pgi genotype and temperature on larval growth and survival in the Glanville fritillary butterfly. Funct. Ecol. 25, 1032-1039.

Karl, I., Schmitt, T. and Fischer, K. 2008. Phosphoglucose isomerase genotype affects life-history traits and cold stress resistance in a Copper butterfly. Funct. Ecol. 22, 887-894.

Kofler, R., Torres, T. T., Lelley, T. and Schlotterer, C. 2009. PanGEA, Identification of allele specific gene expression using the 454 technology. BMC Bioinformatics 10, 143.

Koštál, V., Renault, D., Mehrabianová, A. and Bastl, J. 2007.. Insect cold tolerance and repair of chill-injury at fluctuating thermal regimes, Role of ion homeostasis. Comp. Biochem. Phys. A 147, 231-238.

Laayouni, H, García-Franco, F, Chávez-Sandoval, B, Trotta, V, Beltran, S, Corominas, M and Santos, M 2007. Thermal evolution of gene expression profiles in Drosophila subobscura. BMC Evol. Biol. 7, 42.

Lee, R.E., Chen, C.-P. and Denlinger, D.L. 1987. A Rapid Cold-Hardening Process in Insects. Science 238, $1415-1417$. Li, A. and Denlinger, D.L. 2008. Rapid cold hardening elicits changes in brain protein profiles of the flesh fly, Sarcophaga crassipalpis. Insect Mol. Biol. 17, 565-572.

Mann, K., Mechling, D.E., Bächinger, H.P., Eckerskorn, C., Gaill, F. and Timpl, R. 1996. Glycosylated threonine but not 4-hydroxyproline dominates the triple helix stabilizing positions in the sequence of a hydrothermal vent worm cuticle collagen. J. Mol. Biol. 261, 255-266.

Michaud, M. and Denlinger, D.L. 2007. Shifts in the carbohydrate, polyol, and amino acid pools during rapid coldhardening and diapause-associated cold-hardening in flesh flies Sarcophaga crassipalpis., a metabolomic comparison. J. Comp. Physiol. B 177, 753-763. 
Overgaard, J., Sørensen, J.G., Petersen, S.O., Loeschcke, V. and Holmstrup, M. 2005.. Changes in membrane lipid composition following rapid cold hardening in Drosophila melanogaster. J. Insect Physiol. 51, 1173-1182.

Pfaffl, M.W. 2001. A new mathematical model for relative quantification in real-time RT-PCR. Nucleic Acids Res. 29, 2002-2007

Purać, J., Burns, G., Thorne, M.A.S., Grubor-Lajšić, G., Worland, M.R. and Clark, M.S. 2008. Cold hardening processes in the Antarctic springtail, Cryptopygus antarcticus, Clues from a microarray. J. Insect. Physiol. 54, 1356-1362.

Qin, W., Neal, S.J., Robertson, R.M., Westwood, J.T. and Walker, V.K. 2005. Cold hardening and transcriptional change in Drosophila melanogaster. Insect Mol. Biol. 14, 607-613.

R Development Core Team 2012. R, A language and environment for statistical computing. Vienna, Austria, $R$ Foundation for Statistical Computing. Retrieved from http,//www.R-project.org.

Ramakers, C., Ruijter, J.M., Deprez, R.H.L. and Moorman, A.F.M. 2003. Assumption-free analysis of quantitative real-time polymerase chain reaction PCR. data. Neurosci. Lett. 339, 62-66.

Rank, N.E., Bruce, D.A., McMillan, D.M., Barclay, C. and Dahlhoff, E.P. 2007. Phosphoglucose isomerase genotype affects running speed and heat shock protein expression after exposure to extreme temperatures in a montane willow beetle. J. Exp. Biol. 210, 750-764.

Rinehart, J.P., Li, A., Yocum, G.D., Robich, R.M., Hayward, S.A. and Denlinger, D.L. 2007. Up-regulation of heat shock proteins is essential for cold survival during insect diapause. Proc. Natl. Acad. Sci. USA 104, 1113011137.

Robich, R.M., Rinehart, J.P., Kitchen, L.J. and Denlinger, D.L. 2007. Diapause-specific gene expression in the northern house mosquito, Culex pipiens L., identified by suppressive subtractive hybridization. J. Insect Physiol. 53, 235-245.

Robinson, M.D., McCarthy, D.J. and Smyth, G.K. 2010. edgeR, a Bioconductor package for differential expression analysis of digital gene expression data. Bioinformatics 26, 139-140.

Rowland, L.J., Dhanaraj, A.L., Naik, D., Alkharouf, N., Matthews, B. and Arora, R. 2008. Study of Cold Tolerance in Blueberry Using EST Libraries, cDNA Microarrays, and Subtractive Hybridization. HortSci. 43, 1975-1981.

Rozen, S. and Helen, J. 2000. Primer3 on the WWW for general users and for biologist programmers. In, Krawetz S, Misener S eds. Bioinformatics Methods and Protocols, Methods in Molecular Biology. Humana Press, Totowa, NJ, pp 365-386.

Salmon, J.T. 1991. The Stick Insects of New Zealand. Reed, Auckland, New Zealand

Shoulders, M.D. and Raines, R.T. 2009. Collagen Structure and Stability. Annu. Rev. Biochem. 78, 929-958.

Sinclair, B.J., Worland, M.R., and Wharton, D.A. 1999. Ice nucleation and freezing tolerance in New Zealand alpine and lowland weta, Hemideina spp. Orthoptera; Stenopelmatidae.. Physiol. Entomol. 24, 56-63.

Sinclair, B.J., Vernon, P., Klok, C.J. and Chown, S.L. 2003. Insects at low temperatures, an ecological perspective. Trends Ecol. Evol. 18, 257-262.

Sinclair, B.J., Gibbs, A.G. and Roberts, S.P. 2007. Gene transcription during exposure to, and recovery from, cold and desiccation stress in Drosophila melanogaster. Insect Mol. Biol. 16, 435-443.

Sørensen, J.G., Nielsen, M.M. and Loeschcke, V. 2007. Gene expression profile analysis of Drosophila melanogaster selected for resistance to environmental stressors. J. Evol. Biol. 20, 1624-1636.

Storey, K.B. and Storey, J.M. 2012. Insect cold hardiness, metabolic, gene, and protein adaptation. Can. J. Zool. 90, 456-475

Sundstrom, J.F., Vaculova, A., Smertenko, A.P., Savenkov, E.I., Golovko, A., Minina, E., Tiwari, B.S., RodriguezNieto, S., Zamyatnin, A.A., Valineva, T., Saarikettu, J., Frilander, M.J., Suarez, M.F., Zavialov, A., Stahl, U., Hussey, P.J., Silvennoinen, O., Sundberg, E., Zhivotovsky, B. and Bozhkov, P.V. 2009. Tudor staphylococcal nuclease is an evolutionarily conserved component of the programmed cell death degradome. Nature Cell Biol. 11, 1347-1354. 
Teets, N.M., Peyton, J.T., Ragland, G.J., Colinet, H., Renault, D., Hahn, D.A. and Denlinger, D.L. 2012. Uncovering molecular mechanisms of cold tolerance in a temperate flesh fly using a combined transcriptomic and metabolomic approach. Physiol. Genomics 44, 764-2012

Vandesompele, J., De Preter, K., Pattyn, F., Poppe, B., Van Roy, N., De Paepe, A. and Speleman, F. 2002. Accurate normalization of real-time quantitative RT-PCR data by geometric averaging of multiple internal control genes. Genome Biol. 3, research0034

Vonk, L.A., Doulabi, B.Z., Huang, C.-L., Helder, M.N., Everts, V. and Bank, R.A. 2010. Endoplasmic reticulum stress inhibits collagen synthesis independent of collagen-modifying enzymes in different chondrocyte populations and dermal fibroblasts. Biochem Cell. Biol. 88, 539-552.

Wang, Z., Gerstein, M. and Snyder, M. 2009. RNA-Seq, a revolutionary tool for transcriptomics. Nature Rev. Genet. 10, 57-63.

Weissbach, R. and Scadden, A.D.J. 2012. Tudor-SN and ADAR1 are components of cytoplasmic stress granules. RNA 18, 462-471.

Wharton, D.A. 2011. Cold tolerance of New Zealand alpine insects. J. Insect Physiol. 57, 1090-1095.

Yan, S.P., Zhang, Q.Y., Tang, Z.C., Su, W.A. and Sun, W.N. 2006. Comparative Proteomic Analysis Provides New Insights into Chilling Stress Responses in Rice. Mol. Cell Proteomics 5, 484-496.

Yi, S.X., Moore, C.W. and Lee, R.E. 2007. Rapid cold-hardening protects Drosophila melanogaster from coldinduced apoptosis. Apoptosis 12, 1183-93.

Ying, M. and Chen, D. 2012. Tudor domain-containing proteins of Drosophila melanogaster. Develop. Growth Differ. 54, 32-43

Zhang, J., Marshall, K.E., Westwood, J.T., Clark, M.S. and Sinclair, B.J. 2011. Divergent transcriptomic responses to repeated and single cold exposures in Drosophila melanogaster. J. Exp. Biol. 214, 4021-4029.

Zieger, M., Gupta, M. and Wang, M. 2011. Proteomic analysis of endothelial cold-adaptation. BMC Genomics 12 , 630.

\section{Figures}

Figure 1: Species distribution of the top BLASTx matches for each annotated contig from the de novo assembled Micrarchus nov. sp. 2 transcriptome. Out of the 5,235 contigs, 2,060 (39 \%) matched entries in the non redundant protein ( $\mathrm{nr}$ ) database using Blast2GO (E-value cut-off $<1^{-10}$ ).

Figure 2: Volcano plot showing relative mRNA abundances of each contig in the Micrarchus nov. sp. 2 transcriptome between non cold-treated Individuals and those exposed to $0{ }^{\circ} \mathrm{C}$ for one hour, with a further hour recovery $(n=2)$. Differential expression analysis was performed with an exact test approach using edgeR with common dispersion. Grey points = contigs with $P$-value $>0.05$, black points $=$ contigs with $P$-value $<0.05$. Shaded boxes represent areas with a significant $P$-value and at least a twofold change in mRNA abundance as a result of treatment. Contigs where expression is not recorded in one of the treatments, resulting in an infinite fold change, are not plotted. The three contigs verified as differentially expressed using qPCR are labelled: prolyl 4-hydroxylase subunit alpha-1 (P4HA1), staphylococcal nuclease domain-containing protein 1 (snd1) and a cuticular protein analogous to peritrophins 3-D2 (Cpap3-d2). 
525 Figure 3: Boxplots showing relative mRNA abundance from qPCR for each gene between non cold-

526 treated (white box plots) Micrarchus nov. sp. 2 individuals and those exposed to $0{ }^{\circ} \mathrm{C}$ for one hour, with

527 a further hour recovery (grey box plot) $(n=3)$. Boxplot pairs on a grey background represent the

528 reference genes used for normalisation of abundances between treatments. Boxplots on white

529 background in top panel depict differentially expressed genes identified from RNA-Seq data (Table 2).

530 Boxplots on white background in bottom panel shows a priori genes identified in previous studies

531 (Table 3). ${ }^{*}=$ samples with significant t-test $P$-values $(<0.05)$ from natural log transformed relative

532 abundance values. Dark line indicates median, box represents $25^{\text {th }}$ and $75^{\text {th }}$ percentile with whiskers

533 representing maximum and minimum values. 
535 Table 1: The number of raw 454 sequences obtained for each Micrarchus nov. sp. 2 cDNA library, its 536 treatment, and the percentage used in the final de novo transcriptome alignment. Raw data was 537 submitted to the National Centre for Biotechnology and Information (NCBI) with Sequence Read 538 Archive (SRA) submission number SRA057228.

539

\begin{tabular}{|c|c|c|c|}
\hline Sample & Treatment & \# Sequences & \# Sequences in alignment \\
\hline МMT016 & Cold-shock & 101,379 & $79,382(78.3 \%)$ \\
\hline МMT017 & Cold-shock & 107,242 & $81,039(75.6 \%)$ \\
\hline ММт018 & Control & 160,584 & $124,300(77.4 \%)$ \\
\hline ММт019 & Control & 154,915 & 118,845 (76.8\%) \\
\hline ММт086 & Control & 44,480 & \multirow{2}{*}{$68,779(82.8 \%)$} \\
\hline ММт0135 & Cold-shock & 38,632 & \\
\hline & Total: & 607,232 & $472345(77.8 \%)$ \\
\hline
\end{tabular}

540 
542

543

544

545

546

547

548

549

550

Table 2: Differential expression analysis results for the top ranked up-regulated genes in response to cold-shock from Micrarchus nov. sp. 2 RNA-Seq data. The relative mRNA abundances between individuals exposed to $0{ }^{\circ} \mathrm{C}$ for one hour, with a further hour recovery, were compared to non coldtreated individuals $(n=2)$. Contigs were ranked by $P$-value/Likelihood depending on which analysis was used, boxes shaded grey are non-significant results. Three exact test approaches (edgeR with common dispersion, edgeR with tagwise dispersion and DESeq) and two Bayesian methods (baySeq with and without contig length) were performed. All top four ranked contigs for each analysis shown were selected for validation using qPCR ( $n=11$ due to redundancy between results).

\begin{tabular}{llccccc}
\hline Contig & Results & $\begin{array}{c}\text { edgeR } \\
\text { (common } \\
\text { dispersion) }\end{array}$ & $\begin{array}{c}\text { edgeR } \\
\text { (tagwise } \\
\text { dispersion) }\end{array}$ & DESeq & $\begin{array}{c}\text { baySeq } \\
\text { (without } \\
\text { length) }\end{array}$ & $\begin{array}{c}\text { baySeq } \\
\text { (with } \\
\text { length) }\end{array}$ \\
\hline snd1 & Rank & 22 & 1 & 1 & 859 & 2 \\
& Result & $4.98 \mathrm{E}-03$ & $3.08 \mathrm{E}-04$ & $5.37 \mathrm{E}-03$ & 0.066 & 0.816 \\
C-01744 & Rank & 37 & 30 & 29 & $3 * *$ & 33 \\
& Result & $1.68 \mathrm{E}-02$ & $1.87 \mathrm{E}-02$ & $1.53 \mathrm{E}-01$ & 0.715 & 0.517 \\
Cpap3-d2 & Rank & 46 & 4 & 21 & 1 & $4 * *$ \\
& Result & $1.90 \mathrm{E}-02$ & $3.88 \mathrm{E}-03$ & $1.10 \mathrm{E}-01$ & 0.815 & 0.774 \\
P4HA1 & Rank & 47 & 7 & 24 & 2 & 1 \\
& Result & $2.19 \mathrm{E}-02$ & $5.12 \mathrm{E}-03$ & $1.23 \mathrm{E}-01$ & 0.803 & 0.871 \\
Copia & Rank & 9 & 23 & 4 & 28 & 47 \\
& Result & $2.47 \mathrm{E}-03$ & $1.43 \mathrm{E}-02$ & $3.65 \mathrm{E}-02$ & 0.463 & 0.617 \\
cadn* & Rank & 1 & 2 & 2 & 186 & 77 \\
& Result & $1.72 \mathrm{E}-04$ & $7.79 \mathrm{E}-04$ & $6.49 \mathrm{E}-03$ & 0.207 & 0.352 \\
csde1 & Rank & 21 & 3 & 8 & 10 & 6 \\
& Result & $4.74 \mathrm{E}-03$ & $3.48 \mathrm{E}-03$ & $5.22 \mathrm{E}-02$ & 0.602 & 0.729 \\
C-04525 & Rank & 29 & 22 & 20 & $4 * *$ & $3 * *$ \\
& Result & $7.94 \mathrm{E}-03$ & $1.27 \mathrm{E}-02$ & $1.03 \mathrm{E}-01$ & 0.709 & 0.780 \\
SF3a & Rank & 2 & 5 & 3 & 551 & 55 \\
& Result & $5.12 \mathrm{E}-04$ & $3.88 \mathrm{E}-03$ & $1.57 \mathrm{E}-02$ & 0.109 & 0.422 \\
restin & Rank & 3 & 11 & 7 & 515 & 37 \\
& Result & $2.52 \mathrm{E}-02$ & $8.73 \mathrm{E}-03$ & $4.50 \mathrm{E}-02$ & 0.115 & 0.485 \\
thil* & Rank & 4 & 6 & 6 & 95 & 23 \\
& Result & $1.80 \mathrm{E}-03$ & $4.88 \mathrm{E}-03$ & $4.46 \mathrm{E}-02$ & 0.295 & 0.585 \\
\hline
\end{tabular}

Full contig BLAST annotations are: snd $1=$ staphylococcal nuclease domain-containing protein $1, C-01744=$ non annotated contig 01744, Cpap3-d2 = Cuticular protein analogous to peritrophins 3-D3, P4HA1 = Prolyl 4-hydroxylase subunit alpha-1, Copia $=$ Copia protein, $c a d n=$ neural cadherin, $c s d e 1=$ cold shock domain-containing protein e1, C-04525 = non annotated contig 04525, SF3a $=$ Spliceosome associated protein and restin = restin. Rank of contig out of: 1,186 for edgeR with common dispersion, 1,188 for edgeR with tagwise dispersion, 1,292 for DESeq and 1,145 for both baySeq analyses. Results show $P$-value for edgeR \& DESeq, likelihood for baySeq. ${ }^{*}=$ contig not used in subsequent qPCR analysis due to non-specific amplification of target DNA. ${ }^{* *}=$ in the top four up-regulated genes for baySeq analyses, but the robust approach means the likelihood value is non-significant. 
560 Table 3: The eight a priori candidate genes for qPCR analysis present in the Micrarchus nov. sp. 2

561 transcriptome that have been previously identified in low temperature studies as having a role in cold

562 tolerance. All genes/proteins were shown to be up-regulated in response to low temperature except for

563 glna2 (gene product up-regulated) and pgi (genotype, not regulation, affects cold stress resistance).

\begin{tabular}{|c|c|c|}
\hline Gene & & Species \\
\hline atpa & ATP synthase subunit alpha & Sarcophaga crassipalpis (Li and Denlinger, 2008) \\
\hline glna2 & glutamine synthetase 2 & S. crassipalpis (Michaud and Denlinger, 2007) \\
\hline hsp70 & heat shock protein 70 & Aphidius colemani (Colinet et al., 2007) \\
\hline hsp90 & heat shock protein 90 & Drosophila melanogaster (Qin et al., 2005) \\
\hline NDUFA & NADH: ubiquinone dehydrogenase & Oryza sativa* (Yan et al., 2006) \\
\hline pgi & phosphoglucose isomerase & $\begin{array}{l}\text { Melitaea cinxia (Kallioniemi and Hanski, 2011), } \\
\text { Lycaena tityrus (Karl et al., 2008), Chrysomela } \\
\text { aeneicollis (Rank et al., 2007) }\end{array}$ \\
\hline dcam & $\begin{array}{l}\text { S-adenosylmethionine decarboxylase } \\
\text { proenzyme }\end{array}$ & Vaccinium corymbosum* (Rowland et al., 2008) \\
\hline sahha & S-adenosyl-I-homocysteine hydrolase a & Homo sapiens* (Zieger et al., 2011) \\
\hline
\end{tabular}

$565 *$ = are genes from species that are not insects. These genes were selected for qPCR analysis as they were also in the top $10 \%$ 


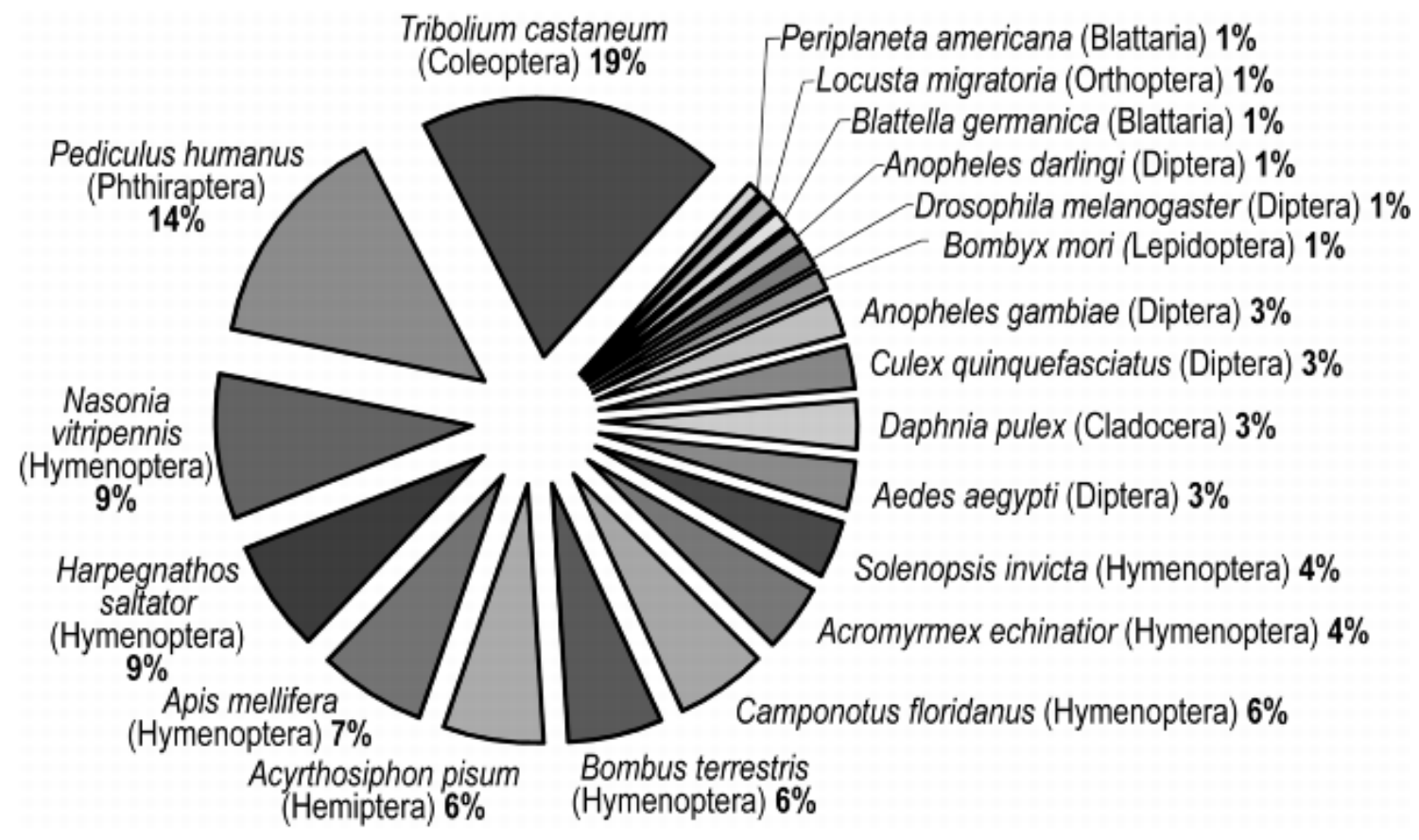

Figure 1 


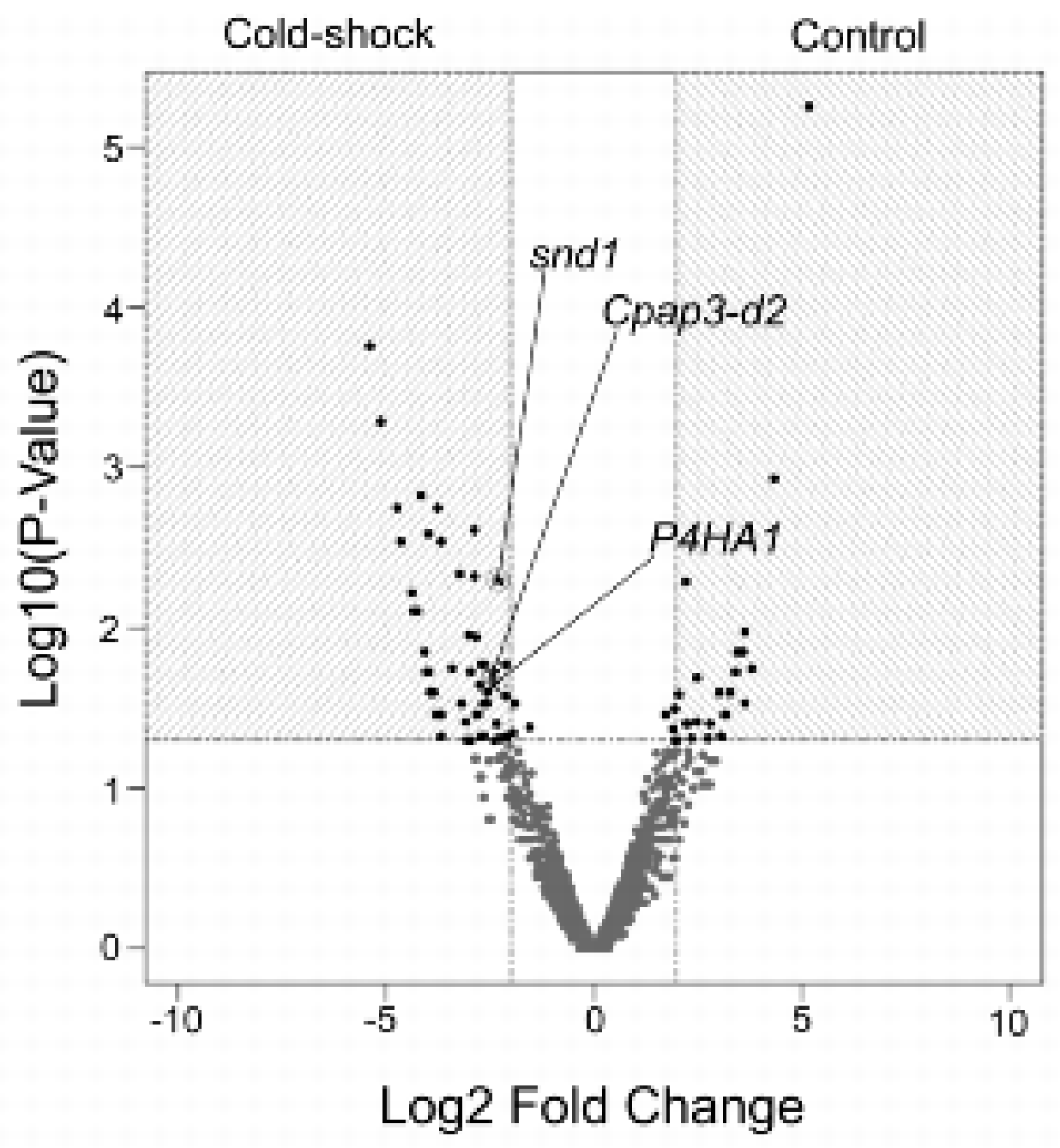

Figure 2 

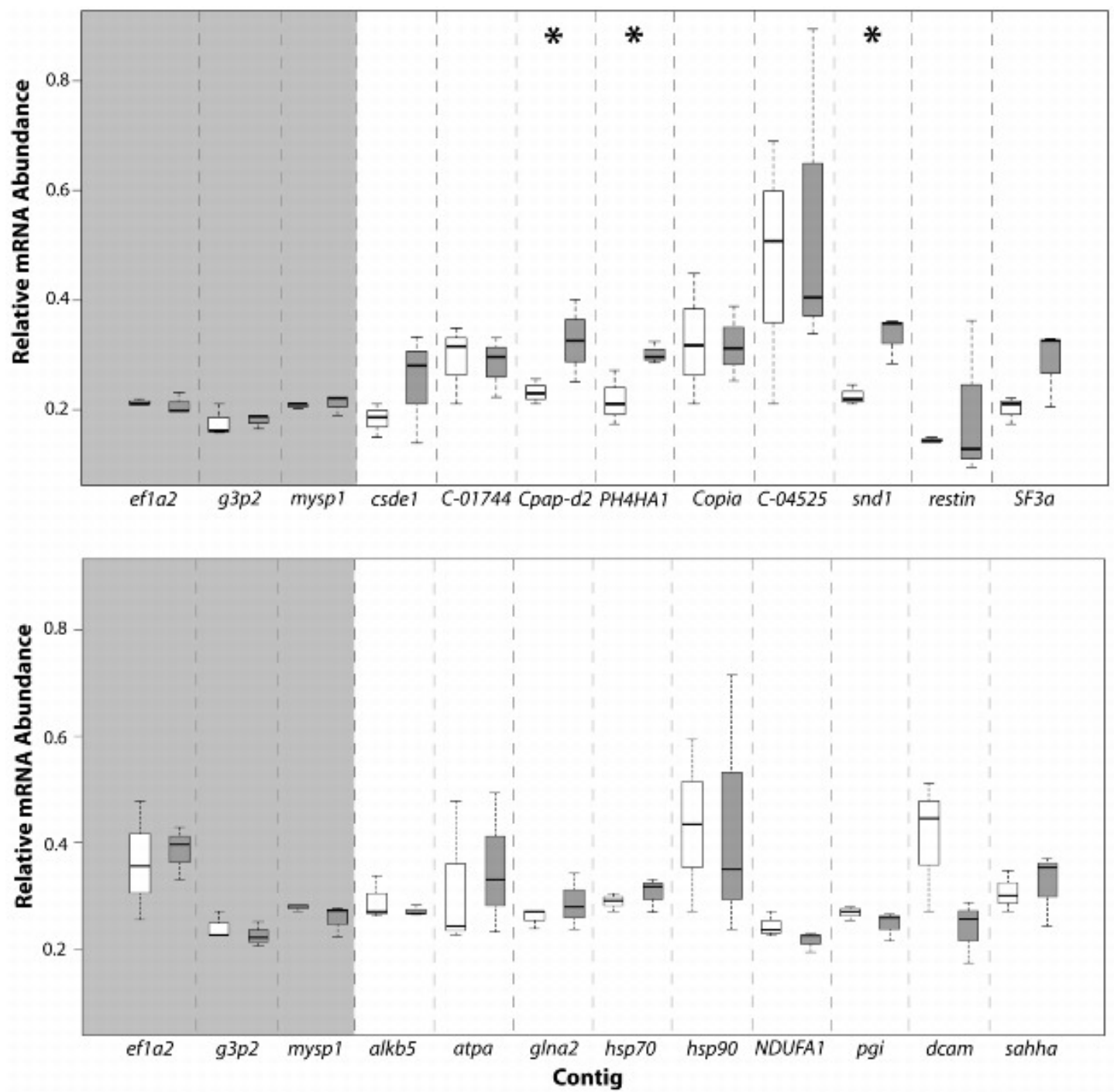

Figure 3 


\section{Supplementary material A -Primer sequences for RT-qPCR. Annotations from BLASTx against}

\section{SwissProt database unless otherwise stated.}

\begin{tabular}{|c|c|c|}
\hline Annotation (e-value $<1^{-10}$ ) & Primer & Sequence (5' - 3') \\
\hline atp synthase subunit alpha & atpa_F1 & TCGAGCGCGAGTTCCTCCAA \\
\hline (atpa) & atpa_R1 & TTGCCCTCCTTCGCGATGCT \\
\hline Paramyosin long form & mysp1_F1 & TGCTTGGCGCGGATAAGCGA \\
\hline (mysp1) & mysp1_R1 & AGGCAGCTACAAGAACAGGAGGGC \\
\hline glutamine synthetase 2 cytoplasmic & glna2_F1 & TCTTCGCGCATCGCCTTGGT \\
\hline (glna2) & glna2_R1 & TCGTGGTGACCTTCGACCCCAA \\
\hline $\begin{array}{l}\text { s-adenosylmethionine decarboxylase proenzyme } \\
(\text { dcam })\end{array}$ & $\begin{array}{l}\text { dcam_F1 } \\
\text { dcam_R1 }\end{array}$ & $\begin{array}{l}\text { CACGTTTGACCTGTTCATACCAGCG } \\
\text { ACCAATGAGAGGGACAGCAAGAACA }\end{array}$ \\
\hline heat shock protein 90 & hsp90_F1 & CATGCGGCCAGGATATACCGCA \\
\hline$(h s p 90)$ & hsp90_R1 & AGCATCCTCGCCTTCCGCTT \\
\hline staphylococcal nuclease domain-containing protein 1 & snd1_F1 & TCGCAAAAGCTCGCACCGCT \\
\hline (snd1) & snd1_R1 & TGTGCСTCTCTCССTTCAGGCT \\
\hline heat shock protein 70 & hsp70_F1 & GGGGATGGTGGTGTTGCGCTTT \\
\hline$(h s p 70)$ & hsp70_R1 & GCCATCTTGGCTGGCGACAAGT \\
\hline elongation factor 1 -alpha 2 & ef1a2_F1 & TCTCTGCCCTGCCGACTGTCAT \\
\hline (ef1a2) & ef1a2_R1 & ACCGGCCTTTCCTGCGAAACT \\
\hline Unannotated contig01744 & C-01744_F1 & TGCGAAGACAAGCTTTAGAGACCGT \\
\hline$(C-01744)$ & C-01744_R1 & ACCCTCTTAAGGACGAGCGCCA \\
\hline s-adenosyl-I-homocysteine hydrolase a & sahha_F1 & GCTGCCTGCAGCGCATTTATGG \\
\hline (sahha) & sahha_R1 & TGTTGGCGGGAAAGGTGGCA \\
\hline glyceraldehyde-3-phosphate dehydrogenase 2 & g3p2_F1 & ACCGTCCCTCCACAACTTGCCA \\
\hline$(g 3 p 2)$ & g3p2_R1 & TGGCACCACTTGCCAAGGTCA \\
\hline Unannotated contig01822 & C-01822_F1 & AGGTGAAGCCGAAAGGTTGGCA \\
\hline$(C-01822)$ & C-01822_R1 & AGGACTGCGAAATCGTCCTCC \\
\hline Phosphoglucose isomerase & pgi_F1 & ACTACGCCACAGGCCCCATAGT \\
\hline$(p g i)$ & pgi_R1 & TGGTGGATCAGCTGGTAGAAGGC \\
\hline Unannotated contig02740 & C-02740_F1 & AGATGGTTACACATGCCACACCCAA \\
\hline$(C-02740)$ & C-02740_R1 & ACAGGCAAGGGTGTGTTGCCA \\
\hline Unannotated contig02855 & C-02855_F1 & AGCCTTGACACCACTCCTTCCAAC \\
\hline$(C-02855)$ & C-02855_R1 & TGAAGACTGCGGGTGAGCTGT \\
\hline probable alpha-ketoglutarate-dependent dioxygenase & alkb5_F1 & TCGTTTCGACAGTTGCGACCCA \\
\hline (alkb5) & alkb5_R1 & TGACCGGGCCCCTCTTAGAAACA \\
\hline
\end{tabular}




\begin{tabular}{lll}
\hline cold shock domain-containing protein e1 & csde1_F1 & TTGTCGCCAGAACGCAGGGT \\
(csde1) & csde1_R1 & AACCGCGGGGAGTGCTTCTT \\
\hline Unannotated contig04525 & C-04525_F1 & TGCTTTGGAGGCGGGCTTGT \\
$($ C-04525) & C-04525_R1 & CGGCAACAGCGAAGTGCTGA \\
\hline nadh: ubiquinone dehydrogenase (BLAST x/ nr) & NDUFA1_F1 & TGTCTTGGGAGTTGCTTTGAAGTGG \\
(NDUFA1) & NDUFA1_R1 & GGACACGGTGGTACTGTGTTTGACA \\
\hline Tribolium castaneum spliceosome associated protein & SF3a_F1 & GGCTGGCCAAAGAAGCCAAGGA \\
mrna (BLAST n / nr) (SF3a) & SF3a_R1 & TTGCTGCAGTTGGCGTGGCT \\
\hline restin & restin_F1 & TCCACCAGCCTCTGCAAGTCCT \\
(restin) & restin_R1 & TGACGCGTGCTGCCAGTCAA \\
\hline
\end{tabular}


Supplementary material - File B - Contigs from Micrarchus nov. sp. 2 transcriptome used for qPCR analysis

\begin{tabular}{|c|c|c|c|c|c|c|c|c|c|c|c|c|c|}
\hline & Selected $^{1}$ & $\begin{array}{l}\text { Contig } \\
\text { Length } \\
\text { (bp) }\end{array}$ & $\begin{array}{c}\text { BLASTx against } \mathrm{nr} \\
\text { database }\end{array}$ & E-Value & $\begin{array}{c}\text { BLASTn against } \mathrm{nr} \\
\text { database }\end{array}$ & E-Value & $\begin{array}{c}\text { BLASTx against SwissProt } \\
\text { database }\end{array}$ & $\begin{array}{c}\text { E- } \\
\text { Value }\end{array}$ & $\begin{array}{l}\text { MMT16 } \\
\text { (cold- } \\
\text { shock) } \\
\text { Counts }^{2}\end{array}$ & $\begin{array}{l}\text { MMT17 } \\
\text { (cold- } \\
\text { shock) } \\
\text { Counts }\end{array}$ & $\begin{array}{l}\text { MMT18 } \\
\text { (control) } \\
\text { Counts }^{2}\end{array}$ & $\begin{array}{l}\text { MMT19 } \\
\text { (control) } \\
\text { Counts }^{2}\end{array}$ & $\begin{array}{l}\text { qPCR } \\
\text { one- } \\
\text { tailed } t- \\
\text { test } P \text { - } \\
\text { value }\end{array}$ \\
\hline P4HA1 & $\mathrm{DE}$ & 755 & $\begin{array}{l}\text { Prolyl 4-hydroxylase } \\
\text { subunit alpha-1 } \\
\text { [Acromyrmex } \\
\text { echinatior] }\end{array}$ & $3.21 \mathrm{E}-120$ & $\begin{array}{l}\text { PREDICTED: Nasonia } \\
\text { vitripennis prolyl 4- } \\
\text { hydroxylase subunit alpha- } \\
\text { 2-like (LOC100116138), } \\
\text { mRNA }\end{array}$ & $3.45 \mathrm{E}-105$ & $\begin{array}{l}\text { Prolyl 4-hydroxylase subunit } \\
\text { alpha-1; Short=4-PH alpha-1; } \\
\text { AltName: Full=Procollagen- } \\
\text { proline,2-oxoglutarate-4- } \\
\text { dioxygenase subunit alpha-1 }\end{array}$ & $\begin{array}{l}5.78 \mathrm{E}- \\
91\end{array}$ & 17 & 14 & 2 & 3 & 3.27E-02 \\
\hline$C-04525$ & $\mathrm{DE}$ & 441 & ---NA--- & ---NA--- & ---NA--- & ---NA--- & ---NA--- & ---NA--- & 9 & 8 & 1 & 0 & $3.65 \mathrm{E}-01$ \\
\hline $\begin{array}{l}\text { Cpap3- } \\
d 2\end{array}$ & $\mathrm{DE}$ & 1333 & $\begin{array}{l}\text { Nasonia vitripennis } \\
\text { cuticular protein } \\
\text { analogous to } \\
\text { peritrophins 3-D2 } \\
\text { (Cpap3-d2), mRNA }\end{array}$ & $1.13 E-160$ & $\begin{array}{l}\text { cuticular protein } \\
\text { analogous to peritrophins } \\
\text { 3-D2 precursor [Tribolium } \\
\text { castaneum] }\end{array}$ & $6.68 \mathrm{E}-120$ & ---NA--- & ---NA--- & 17 & 15 & 3 & 2 & 4.69E-02 \\
\hline csde1 & $\mathrm{DE}$ & 568 & $\begin{array}{l}\text { cold shock domain- } \\
\text { containing protein e1- } \\
\text { like isoform } 3\end{array}$ & $1.2 \mathrm{E}-36$ & $\begin{array}{l}\text { acyrthosiphon pisum cold } \\
\text { shock domain-containing } \\
\text { protein e1- transcript } \\
\text { variant } 3 \mathrm{mrna}\end{array}$ & $1.9 \mathrm{E}-65$ & $\begin{array}{l}\text { csde1_human ame: full=cold } \\
\text { shock domain-containing } \\
\text { protein e1 ame: full=n-ras } \\
\text { upstream gene protein ame: } \\
\text { full=protein unr }\end{array}$ & $2.1 \mathrm{E}-11$ & 30 & 7 & 3 & 2 & $2.01 \mathrm{E}-01$ \\
\hline Copia & $\mathrm{DE}$ & 724 & $\begin{array}{l}\text { hypothetical protein } \\
\text { TcasGA2_TC015470 } \\
\text { [Tribolium castaneum] }\end{array}$ & $4.34 \mathrm{E}-72$ & $\begin{array}{l}\text { Medicago truncatula } \\
\text { chromosome } 8 \text { clone } \\
\text { mth2-182o15, complete } \\
\text { sequence }\end{array}$ & $4.48 \mathrm{E}-12$ & $\begin{array}{l}\text { Copia protein; AltName: } \\
\text { Full=Gag-int-pol protein; } \\
\text { Contains: RecName: } \\
\text { Full=Copia VLP protein; } \\
\text { Contains: RecName: } \\
\text { Full=Copia protease }\end{array}$ & $\begin{array}{l}1.57 E- \\
38\end{array}$ & 43 & 0 & 3 & 2 & $4.91 \mathrm{E}-01$ \\
\hline$C-01744$ & $\mathrm{DE}$ & 1461 & ---NA--- & $\begin{array}{l}--\mathrm{NA}--- \\
\end{array}$ & ---NA--- & $\begin{array}{l}---N A--- \\
\end{array}$ & ---NA--- & ---NA--- & 11 & 10 & 3 & 1 & $4.69 \mathrm{E}-01$ \\
\hline restin & $\mathrm{DE}$ & 285 & $\begin{array}{l}\text { restin (reed-steinberg } \\
\text { cell-expressed } \\
\text { intermediate filament- } \\
\text { associated protein) }\end{array}$ & $3.3 \mathrm{E}-18$ & ---NA--- & ---NA--- & $---N A---$ & ---NA--- & 30 & 0 & 2 & 0 & 3.83E-01 \\
\hline SF3a & DE & 357 & ---NA--- & ---NA--- & $\begin{array}{l}\text { tribolium castaneum } \\
\text { spliceosome associated } \\
\text { protein mrna }\end{array}$ & $5.2 \mathrm{E}-13$ & ---NA--- & ---NA--- & 0 & 28 & 0 & 1 & $6.15 \mathrm{E}-02$ \\
\hline cadn & $\mathrm{DE}$ & 637 & cadherin- isoform $\mathrm{h}$ & $1.7 \mathrm{E}-39$ & $\begin{array}{l}\text { acyrthosiphon pisum } \\
\text { neural-cadherin-like mrna }\end{array}$ & $9.7 \mathrm{E}-51$ & $\begin{array}{l}\text { cadn_drome ame: } \\
\text { full=neural-cadherin ame: } \\
\text { full=cadherin-n short=dn- } \\
\text { cadherin flags: precursor }\end{array}$ & $2.0 \mathrm{E}-31$ & 2 & 33 & 1 & 0 & $N A^{*}$ \\
\hline thil & & & & & & & thil_mouse ame: full=acetyl- & & & & & & \\
\hline
\end{tabular}




\begin{tabular}{|c|c|c|c|c|c|c|c|c|c|c|c|c|c|}
\hline & $\mathrm{DE}$ & 328 & acetoacetyl- thiolase & $2.1 \mathrm{E}-27$ & $\begin{array}{l}\text { tetraodon nigroviridis full- } \\
\text { length cdna }\end{array}$ & $8.6 \mathrm{E}-29$ & $\begin{array}{l}\text { mitochondrial ame: } \\
\text { full=acetoacetyl- thiolase } \\
\text { flags: precursor }\end{array}$ & $2.5 \mathrm{E}-25$ & 4 & 18 & 0 & 1 & $\mathrm{NA}^{*}$ \\
\hline atpa & a priori & 1938 & $\begin{array}{l}\text { atp synthase subunit } \\
\text { mitochondrial }\end{array}$ & $0.0 \mathrm{E}+00$ & $\begin{array}{l}\text { drosophila erecta gg22793 } \\
\text { (dereไgg22793) mrna }\end{array}$ & $0.0 \mathrm{E}+00$ & $\begin{array}{l}\text { atpa_drome ame: full=atp } \\
\text { synthase subunit } \\
\text { mitochondrial ame: } \\
\text { full=protein bellwether flags: } \\
\text { precursor }\end{array}$ & $0.0 \mathrm{E}+00$ & 66 & 61 & 76 & 61 & $3.63 \mathrm{E}-01$ \\
\hline glna2 & a priori & 4702 & $\begin{array}{l}\text { glutamine synthetase } \\
2 \text { cytoplasmic }\end{array}$ & $5.7 E-159$ & $\begin{array}{l}\text { drosophila erecta gg18416 } \\
\text { (derelgg18416) mrna }\end{array}$ & $2.0 \mathrm{E}-158$ & $\begin{array}{l}\text { glna2_drome ame: } \\
\text { full=glutamine synthetase } 2 \\
\text { cytoplasmic ame: } \\
\text { full=glutamate--ammonia } \\
\text { ligase 2 }\end{array}$ & $\begin{array}{l}2.4 \mathrm{E}- \\
149\end{array}$ & 70 & 85 & 48 & 48 & $2.46 \mathrm{E}-01$ \\
\hline dcam & a priori & 3811 & $\begin{array}{l}\text { s-adenosylmethionine } \\
\text { decarboxylase } \\
\text { proenzyme }\end{array}$ & $4.4 \mathrm{E}-144$ & $\begin{array}{l}\text { pediculus humanus } \\
\text { corporis s- } \\
\text { adenosylmethionine mrna }\end{array}$ & $7.4 \mathrm{E}-49$ & $\begin{array}{l}\text { dcam_drome ame: full=s- } \\
\text { adenosylmethionine } \\
\text { decarboxylase proenzyme } \\
\text { short= etdc short=samdc } \\
\text { contains: ame: full=s- } \\
\text { adenosylmethionine } \\
\text { decarboxylase alpha chain } \\
\text { contains: ame: full=s- } \\
\text { adenosylmethionine } \\
\text { decarboxylase beta chain } \\
\text { flags: precursor }\end{array}$ & $\begin{array}{l}1.1 \mathrm{E}- \\
104\end{array}$ & 121 & 140 & 16 & 72 & $5.02 \mathrm{E}-02$ \\
\hline hsp70 & a priori & 2264 & heat shock protein 70 & $0.0 \mathrm{E}+00$ & $\begin{array}{l}\text { drosophila melanogaster } \\
\text { heat shock protein } \\
\text { cognate } 4 \text { (hsc70-4) } \\
\text { transcript variant mrna }\end{array}$ & $0.0 \mathrm{E}+00$ & $\begin{array}{l}\text { hsp7d_manse ame: full=heat } \\
\text { shock } 70 \text { kda protein cognate } \\
4 \text { short=hsc } 70-4\end{array}$ & $0.0 \mathrm{E}+00$ & 253 & 294 & 308 & 258 & $2.48 \mathrm{E}-01$ \\
\hline sahha & a priori & 1453 & $\begin{array}{l}\mathrm{s-} \\
\text { adenosylhomocysteine } \\
\text { hydrolase }\end{array}$ & $0.0 \mathrm{E}+00$ & $\begin{array}{l}\text { tetraodon nigroviridis full- } \\
\text { length cdna }\end{array}$ & $0.0 \mathrm{E}+00$ & $\begin{array}{l}\text { sahha_xenla ame: } \\
\text { full=adenosylhomocysteinase } \\
\text { a short= cyase a ame: full=s- } \\
\text { adenosyl-I-homocysteine } \\
\text { hydrolase a }\end{array}$ & $0.0 \mathrm{E}+00$ & 27 & 33 & 15 & 10 & 4.02E-01 \\
\hline pgi & a priori & 902 & $\begin{array}{l}\text { phosphoglucose } \\
\text { isomerase }\end{array}$ & 2.4E-175 & $\begin{array}{l}\text { drosophila sechellia } \\
\text { gm20655 (dseclgm20655) } \\
\text { mrna }\end{array}$ & $1.7 \mathrm{E}-163$ & $\begin{array}{l}\text { g6pi_droya ame: } \\
\text { full=glucose-6-phosphate } \\
\text { isomerase short=gpi ame: } \\
\text { full=phosphoglucose } \\
\text { isomerase short=pgi ame: } \\
\text { full=phosphohexose } \\
\text { isomerase short=phi }\end{array}$ & $\begin{array}{l}1.7 \mathrm{E}- \\
168\end{array}$ & 3 & 7 & 2 & 4 & 1.47E-01 \\
\hline NDUFA1 & a priori & 428 & $\begin{array}{l}\text { nadh:ubiquinone } \\
\text { dehydrogenase }\end{array}$ & $1.4 \mathrm{E}-33$ & ---NA--- & ---NA--- & ---NA--- & ---NA--- & 13 & 7 & 3 & 1 & $9.65 \mathrm{E}-02$ \\
\hline hsp90 & a priori & 2608 & heat shock protein 90 & $0.0 \mathrm{E}+00$ & $\begin{array}{l}\text { locusta migratoria heat } \\
\text { shock protein } 90 \text { complete } \\
\text { cds }\end{array}$ & $0.0 \mathrm{E}+00$ & $\begin{array}{l}\text { hs90b_horse ame: full=heat } \\
\text { shock protein hsp 90-beta }\end{array}$ & $0.0 \mathrm{E}+00$ & 62 & 47 & 43 & 43 & 4.47E-01 \\
\hline mysp1 & Reference & 3708 & long form-like & $0.0 \mathrm{E}+00$ & nasonia vitripennis long & $0.0 \mathrm{E}+00$ & mysp1_drome ame: full= & $0.0 \mathrm{E}+00$ & 1275 & 1142 & 1477 & 1074 & NA \\
\hline
\end{tabular}




\begin{tabular}{|c|c|c|c|c|c|c|c|c|c|c|c|c|c|}
\hline & & & & & form-like mrna & & long form & & & & & & \\
\hline efia 2 & Reference & 1989 & $\begin{array}{l}\text { elongation factor 1- } \\
\text { alpha }\end{array}$ & $0.0 E+00$ & $\begin{array}{l}\text { drosophila melanogaster } \\
\text { elongation factor } \\
\text { 1alpha48d transcript } \\
\text { variant mrna }\end{array}$ & $0.0 \mathrm{E}+00$ & $\begin{array}{l}\text { ef1a2_drome ame: } \\
\text { full=elongation factor } 1 \text { - } \\
\text { alpha } 2 \text { short=ef-1-alpha-2 }\end{array}$ & $0.0 \mathrm{E}+00$ & 327 & 333 & 350 & 369 & NA \\
\hline$g 3 p 2$ & Reference & 1433 & $\begin{array}{l}\text { glyceraldehyde-3- } \\
\text { phosphate } \\
\text { dehydrogenase }\end{array}$ & $0.0 \mathrm{E}+00$ & $\begin{array}{l}\text { oncometopia nigricans } \\
\text { glyceraldehyde-3- } \\
\text { phosphate dehydrogenase } \\
\text { complete cds }\end{array}$ & $0.0 \mathrm{E}+00$ & $\begin{array}{l}\text { g3p2_drome ame: } \\
\text { full=glyceraldehyde-3- } \\
\text { phosphate dehydrogenase } 2 \\
\text { ame: full=glyceraldehyde-3- } \\
\text { phosphate dehydrogenase ii } \\
\text { short=gapdh ii }\end{array}$ & $0.0 E+00$ & 86 & 70 & 87 & 83 & NA \\
\hline
\end{tabular}

\section{Selected $^{1}=$ Selected for qPCR from the differential expression analysis (DE), from the literature (a priori) or the by eye from the raw counts (Counts)}

Counts $^{2}=$ edge $R$ quantile corrected counts used for differential expression analysis

${ }^{*}=$ not use for qPCR analysis due to non-specific amplification of target DNA based on melt curve $s$ 


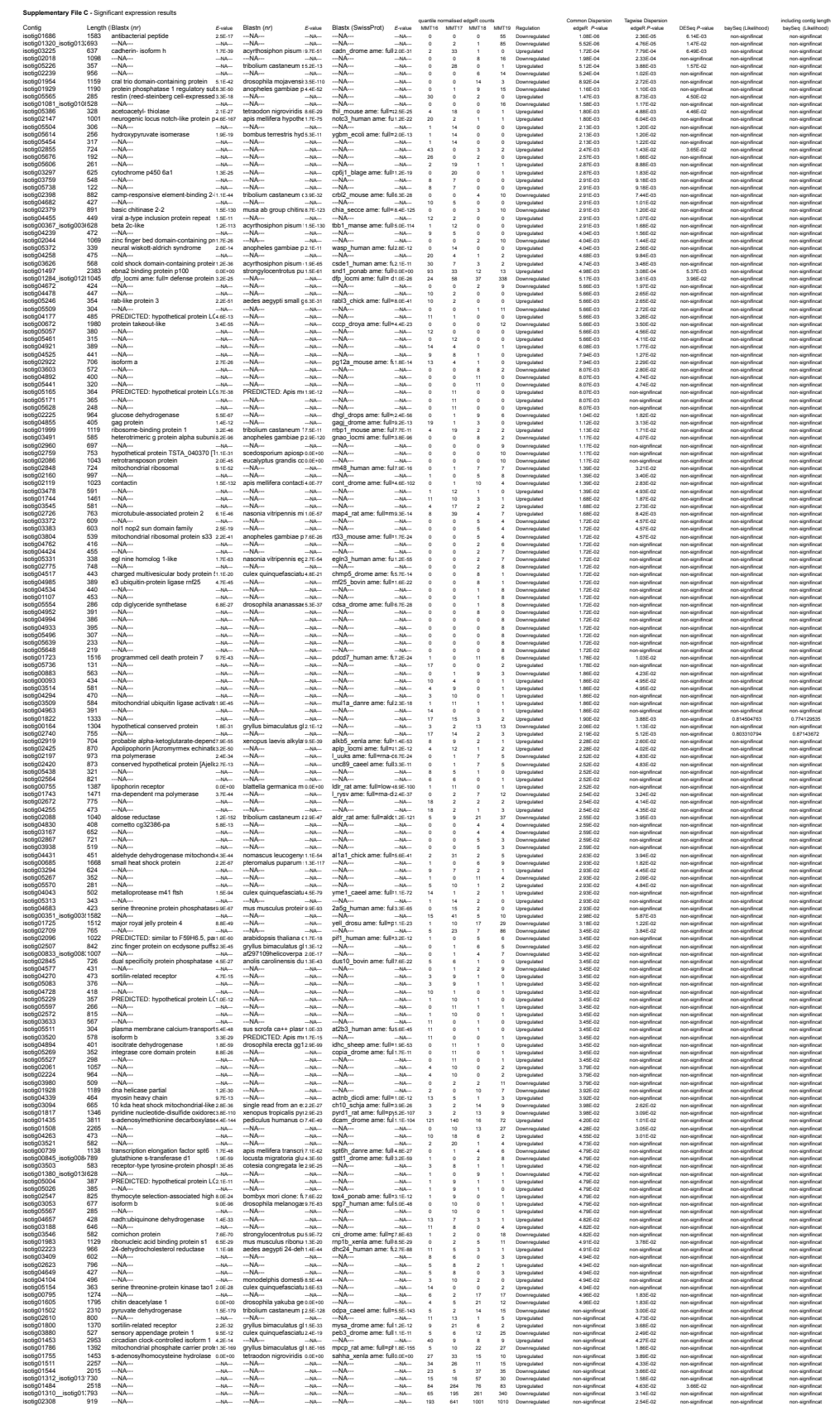

